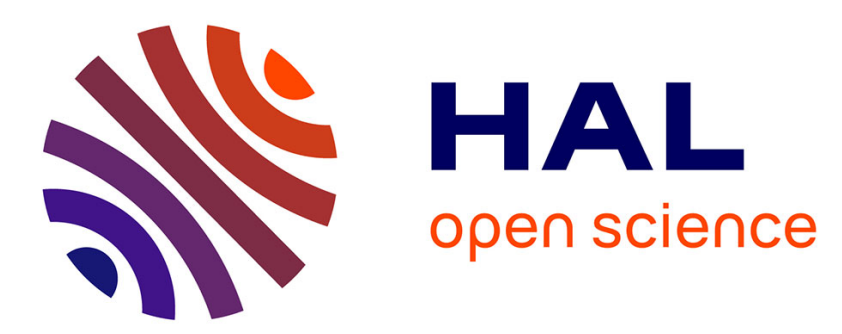

\title{
Effects of spontaneous field margin vegetation on the regulation of herbivores in two winter crops
}

Anna Pollier, Lucille Guillomo, Yann Tricault, Manuel Plantegenest, Armin Bischoff

\section{- To cite this version:}

Anna Pollier, Lucille Guillomo, Yann Tricault, Manuel Plantegenest, Armin Bischoff. Effects of spontaneous field margin vegetation on the regulation of herbivores in two winter crops. Basic and Applied Ecology, 2018, 27, pp.71 - 82. 10.1016/j.baae.2018.02.004 . hal-01778303

HAL Id: hal-01778303

https://hal-univ-avignon.archives-ouvertes.fr/hal-01778303

Submitted on 3 May 2018

HAL is a multi-disciplinary open access archive for the deposit and dissemination of scientific research documents, whether they are published or not. The documents may come from teaching and research institutions in France or abroad, or from public or private research centers.
L'archive ouverte pluridisciplinaire HAL, est destinée au dépôt et à la diffusion de documents scientifiques de niveau recherche, publiés ou non, émanant des établissements d'enseignement et de recherche français ou étrangers, des laboratoires publics ou privés. 


\section{Accepted Manuscript}

Title: Effects of spontaneous field margin vegetation on the regulation of herbivores in two winter crops

Authors: Anna Pollier, Lucille Guillomo, Yann Tricault, Manuel Plantegenest, Armin Bischoff

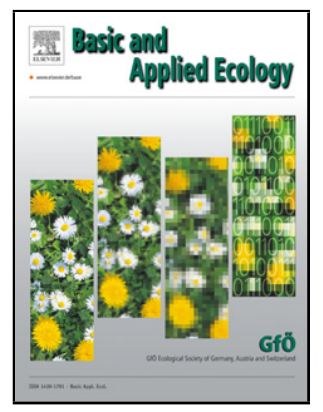

PII: $\quad$ S1439-1791(17)30143-3

DOI: $\quad$ https://doi.org/10.1016/j.baae.2018.02.004

Reference: $\quad$ BAAE 51084

To appear in:

Received date: $\quad$ 19-5-2017

Revised date: $\quad 11-2-2018$

Accepted date: $\quad$ 12-2-2018

Please cite this article as: $\{$ https://doi.org/

This is a PDF file of an unedited manuscript that has been accepted for publication. As a service to our customers we are providing this early version of the manuscript. The manuscript will undergo copyediting, typesetting, and review of the resulting proof before it is published in its final form. Please note that during the production process errors may be discovered which could affect the content, and all legal disclaimers that apply to the journal pertain. 


\title{
Effects of spontaneous field margin vegetation on the regulation of herbivores in two winter crops
}

Anna Pollier a,*, Lucille Guillomo a, Yann Tricault a, Manuel Plantegenest ${ }^{\text {b }}$, Armin Bischoff c

${ }^{\text {a }}$ UMR 1349 Institute of Genetics, Environment and Plant Protection (IGEPP), Agrocampus Ouest, 2 Rue André le Nôtre, 49045 Angers, France

${ }^{\mathrm{b}}$ UMR 1349 Institute of Genetics, Environment and Plant Protection (IGEPP), Agrocampus Ouest, 65 Rue de Saint-Brieuc, 35042 Rennes, France

${ }^{c}$ University of Avignon, Mediterranean Institute of Biodiversity and Ecology (IMBE, AixMarseille University, CNRS, IRD, University of Avignon), IUT Agroparc, BP 61207, 84911 Avignon, France

*Anna Pollier. Tel.: +33 (0)6 26556583 ; fax : +33 (0)2 41225599.

E-mail adress: anna.pollier@gmail.com.

\begin{abstract}
Non-crop vegetation of field margins provides resources for natural enemies of crop herbivores. However, it is still not well known whether this resource provisioning effect is strong enough to improve herbivore regulation within crop fields and which plant species and functional groups favour this ecosystem service. A better understanding of the interactions between field margin vegetation and herbivore regulation is crucial to evaluate management strategies and to design suppressive plant mixtures. We surveyed 64 wheat and oilseed rape fields of Western
\end{abstract}


France for two years (16 fields per year and crop) in order (1) to identify plant diversity or group effects on herbivore regulation within crop fields and (2) to identify species within plant groups that improve regulation. Herbivores, herbivore damage and natural enemies were monitored on crop plants at a distance of 5 and $50 \mathrm{~m}$ from the field margin. At the same time, the cover and phenological stage of all vascular plants were estimated in the adjacent field margin. The study demonstrated a positive relationship between the cover of entomophilous plant species that were flowering at the survey date and response variables related to herbivore regulation. Plant species richness and the cover of plant species taxonomically close to crop plants had a small influence on herbivores and natural enemies in wheat whereas related wild Brassicaceae increased herbivory and decreased herbivore regulation in oilseed rape. Within the entomophilous flowering plants, several species were significantly related to a better herbivore regulation in univariate analyses. Multivariate ordination techniques allowed the identification of plant species influencing several response variables of herbivore regulation at the same time. Our study demonstrated the importance of entomophilous species that flowered at peak infestation of crop herbivores. Spontaneous field margins rich in flowering entomophilous species provide an important ecosystem service without expensive sowing of seed mixtures.

Keywords: Ecosystem service, plant diversity, floristic composition, natural enemies, biological control, wheat, oilseed rape

\section{Introduction}

Arable ecosystems are relatively species-poor and biodiversity of agricultural landscapes is concentrated in non-cultivated, semi-natural habitats, such as field margins, meadows, hedgerows and woods (Bianchi, Booij, \& Tscharntke, 2006; Billeter et al., 2008, Landis 2017). 
As semi-natural habitats provide shelter and resources for natural enemies, crop herbivore regulation is expected to vary with habitat characteristics driving these functions. While relations between the size and proportion of semi-natural habitats in the surrounding landscape and natural enemy abundance are well documented, our knowledge of the role of habitat quality is still relatively poor (Bianchi et al., 2006; Veres, Petit, Conord, \& Lavigne, 2013; Woltz, Isaacs, \& Landis, 2012, Begg et al. 2017). Plant species composition may serve as a proxy of habitat quality reflecting variation in plant traits and thereby mediating plant-insect interactions. In a study on semi-natural grasslands and heathlands, the arthropod assemblage composition was better explained by local plant species composition than by the surrounding landscape (Schaffers, Raemakers, Sýkora, \& ter Braak, 2008). Plants provide shelter and overwintering sites for natural enemies, and plant species composition determines the herbivore community of field margins representing alternative prey during the absence of crop herbivores (Bianchi et al., 2006; Griffiths, Holland, Bailey, \& Thomas, 2008). Floral resources may increase the fitness of natural enemies that change nutrition during their life cycle (Araj \& Wratten, 2015; Winkler, Wäckers, Kaufman, Larraz, \& van Lenteren, 2009) resulting in an improvement of pest control efficiency (Balmer et al., 2014; Blaauw \& Isaacs, 2012; Tylianakis, Didham, \& Wratten, 2004). Interactions between plant species and flower-visiting natural enemies are often speciesspecific (Sivinski, Wahl, Holler, Dobai, \& Sivinski, 2011). So it can be concluded that floral resource provisioning for natural enemies strongly depends on plant species composition (Wäckers \& Van Rijn 2012, Balzan et al. 2014). Studies testing effects of vegetation composition on pest insect regulation focused on sown wildflower strips (Balmer et al., 2013; Haaland, Naisbit, \& Bersier, 2011, Tschumi et al. 2015) and grass strips (Lee, Menalled, \& Landis, 2001; MacLeod, Wratten, Sotherton, \& Thomas, 2004). Plant species grown in such experimental approaches were selected using expert knowledge of flower attractiveness and results obtained from screening experiments in monospecific stands (Sivinski et al., 2011). 
However, studies focusing on spontaneous vegetation of semi-natural habitats such as field margins and their plant species composition are rare and limited to natural enemy level as response variable or very simple vegetation proxies such as species richness (Denys \& Tscharntke 2002, Meek et al. 2002, Chaplin-Kramer et al. 2011, Tscharntke et al. 2011, Diehl et al. 2013, Dassou \& Tixier 2016).

Analyses including both crop herbivores and natural enemies are needed to test the final outcome of plant-insect interactions in terms of crop herbivore regulation. A meta-analysis by Chaplin-Kramer (2011) demonstrated that landscape complexity involving semi-natural habitats usually increased natural enemy densities but this increase did not necessarily translate into an improved regulation of crop herbivores. Wild relatives of crop plants may for example attract crop herbivores and their natural enemies at the same time. An increase of crop herbivore densities in field margins may increase crop infestation and damage by associational susceptibility (Le Guigo, Rolier, \& Le Corff, 2012). Bischoff et al. (2016) showed that wild Brassicaceae species had a predominantly negative influence on herbivore regulation in Brassicaceae crops. In a recent review, beneficial effects of semi-natural habitats on crop herbivores were also cited as a major reason for a failure in enhancing biological control (Tscharntke et al. 2016). Letourneau et al. (2011) still found a better herbivore suppression in agro-ecosystems with higher plant diversity based on 45 published studies but most of the positive results were obtained for intercropping systems and need to be verified for semi-natural habitats outside crop fields.

If crop herbivores are better controlled by a diversity of natural enemies (complementarity hypothesis, Dunning et al. 1992), each being attracted and favoured by particular plant species, then a higher diversity of field margin vegetation may improve crop herbivore regulation. Such a positive plant diversity effect on herbivore regulation has been shown in several studies (Balvanera et al., 2006; Dassou \& Tixier, 2016 and citations therein). A better knowledge of 
spontaneous vegetation effects is required to identify candidate species for designing wildflower strip seed mixtures. Spontaneous vegetation may be natural or spontaneously developing under human management without sowing (semi-natural). Spontaneously occurring species have already proven to be well adapted to local environmental conditions. So, they present an interesting species pool to expand existing wildflower strip mixtures with often similar and limited species combinations.

In this study, we examine the relationships between the spontaneous field margin flora and the abundance of natural enemies, pest insects and crop damage in wheat and oilseed rape. Both commonly grown winter crops succeed each other in typical crop rotations of the study region (Valantin-Morison, Meynard, \& Doré, 2007). Due to their taxonomic distance (wheat: Poaceae, monocotyledon; oilseed rape: Brassicaceae, dicotyledon), they show large morphological and physiological differences and do not share major herbivores. We selected these two taxonomically distant crops associated with different herbivore communities to evaluate whether they still share plant species exerting regulatory effects on dominant crop herbivores. The major natural enemy groups regulating herbivores of both crops are parasitoids, hoverflies, ladybugs, lacewings and ground beetles (Tschumi, Albrecht, Entling, \& Jacot, 2015; ValantinMorison et al., 2007). In order to obtain general information on beneficial effects of field margin vegetation on herbivore regulation in both crops, we focus on (1) the cover of entomophilous, nectar-producing plants, (2) the cover of wild relatives of crop plants (same family) and (3) plant species richness.

We address the following questions:

1. Do plant species composition (functional and taxonomic groups) and richness of field margins affect crop herbivores and their natural enemies in the field? 
2. Is there a set of plant species or species groups associated with a better regulation of different herbivores?

3. Are relationships between field margin vegetation and crop herbivore regulation similar in two winter crops often grown in succession and are they also detectable at larger distances from the field margin?

\section{Materials and methods}

\section{Study sites and experimental design}

The study sites were located in the Maine-et-Loire department of Western France (Fig. 1A). The agricultural landscape is dominated by wheat, oilseed rape, maize, vegetable fields and permanent grasslands. We used wheat (Triticum aestivum and Triticum durum) and oilseed rape (Brassica napus) as model systems. Sixteen winter wheat and sixteen oilseed rape fields were monitored in each of two consecutive years (2014 and 2015) resulting in a total of 64 analysed fields (Fig. 1B). Minimum distance between fields of the same year and crop was $1 \mathrm{~km}$. Field management was not standardised and is representative of the study region ranging from organic (2-3 per crop and year) to conventional (13-14 per crop and year). No insecticide treatment was applied to wheat fields during the study period whereas conventional oilseed rape fields were on average treated twice a year against pollen beetles and weevils, respectively. Pollen beetles and weevils were still among the most common crop herbivores in the selected oilseed rape fields allowing a robust analysis of flora effects (Table S1A).

Field margins were $>2 \mathrm{~m}$ wide strips of spontaneous herbaceous vegetation, in particular perennial herbs and grasses. Woody field margins and margins dominated by annual weeds or ruderal species indicating recent disturbance were excluded from this study. We only 
considered the non-cultivated part outside the field as a margin. Usually, margins were managed by cutting once a year during summer.

\section{Vegetation surveys}

All vascular plants were recorded in a survey area of $75 \mathrm{~m}^{2}$ with a width ranging from $2 \mathrm{~m}$ to 5 $\mathrm{m}$ (average: $3 \mathrm{~m}$, Fig. 1C). The cover of each plant species was measured as the vertical projection of all aboveground organs using the Braun-Blanquet method (Braun-Blanquet 1964). Instead of applying estimation scales, we directly estimated cover percentage (Damgaard 2014) by first analysing the frequent species from outside the survey area then rarer or less visible species inside. A cover of $0.1 \%$ was fixed as detection limit including species covering less than $0.075 \mathrm{~m}^{2}$. In order to evaluate floral resource availability, we additionally estimated the percentage of flowering plants for each species. The cover of flowering plants was calculated by multiplying plant cover and flowering percentage of all recorded plant species. The vegetation surveys were conducted during the flowering period of the crop plants, in May for oilseed rape and in June for wheat.

\section{Arthropod observations and surveys}

Crop herbivores, related damage and natural enemies were recorded in each field at a distance of 5 and $50 \mathrm{~m}$ from the vegetation survey plot in the field margin (Fig. 1C). The survey dates corresponded to the main phenological stages of crops and peak attack of major crop herbivores. Wheat was monitored twice a year in early and late June, at stages of spikelet emergence and early milk ripening. These two stages usually coincide with the peak occurrence of two major pests, cereal leaf beetle larvae (Oulema ssp.) and cereal aphids (Sitobion avenae and Metopolophium dirhodum). In each wheat field and for each sampling date, 50 randomly chosen tillers per distance were observed. The two major pests and their predators (ladybugs, Coccinellidae and hoverflies, Syrphidae) were counted on each tiller (Table S1). Aphid 
parasitism rate (Hymenoptera, various species) was measured for each of the two distances, by dividing the total number of mummies per tiller by the sum of aphids and mummies. Leaf beetle damage was estimated by visual observation as the mean percentage of removed tissue on all green leaves of each tiller.

Oilseed rape was monitored three times a year in April, May and June at stages of flower bud appearance, flowering peak and early fruiting. These stages characterise peak attack by pollen beetles, aphids and pod midges often following pod weevil attack. In each oilseed rape field and for each sampling date, twenty plants per distance (randomly chosen except for suction sampling) were observed or sampled. In April, pollen beetle (Meligethes aeneus) adults were captured along a line of twenty consecutive plants using a suction sampler (Stihl sh 86-d). Suction time was 10 min per distance and field. In May, stem weevil damage (Ceutorhynchus napi) was recorded as the number of plants with characteristic symptoms (burst or deformed stems). The main flowering stem of twenty plants was harvested to count pollen beetle larvae and to evaluate parasitism. Samples were frozen before removal and dissection of larvae under a binocular loupe. The head of the larvae was cut and inner organs were removed to check for the presence of parasitoid eggs. In June, aphids (Brevicoryne brassicae), adult parasitoids (dominant species: Diaeretiella rapae), hoverflies (Syrphidae, larvae and adults) and ladybugs (Coccinellidae, larvae and adults) were counted by visual observation. Aphid parasitism was calculated from aphid and mummy numbers as for wheat. Pod damage caused by fruit weevils (Ceutorhynchus assimilis) was recorded on the main inflorescence as the ratio of attacked pods (holes) to total pod number.

\section{Data analysis}

The relationships between the explanatory (floristic composition) and response variables (crop herbivores, damage, natural enemies including parasitism, Table S1) were tested using 
generalised linear mixed models (GLMM). Analyses were run separately for the two crop species (wheat, oilseed rape) and distances $(5 \mathrm{~m}, 50 \mathrm{~m})$. Observation dates within the same year were pooled if the same insects or damage types were observed twice. In order to avoid overparametrisation of statistical models, the analyses were run in two steps. In a first step, plant species number (total species richness), the cover (\%) of entomophilous flowering plants and the cover $(\%)$ of taxonomically related plants (Poaceae for wheat and Brassicaceae for oilseed rape) were fitted as explanatory variables. The biolflor database (Klotz, Kühn, \& Durka, 2002) was used to identify entomophilous plants. In this data base, plant species that are predominantly pollinated by insects are considered as entomophilous. Only species flowering at the survey date were included in this group. Year was fitted as a random factor to account for potential variation between years and sites since fields within crops were not the same in both years. In a second step, we reran the analysis using individual plant species within the plant group providing the best model fit in the first step which was the entomophilous species group in both crops. The cover of each species within this group was fitted as explanatory variable. Again to avoid overparametrisation, rare plant species occurring in less than one third of the field margins were omitted from this analysis. In both steps, we applied a stepwise backward procedure to identify the best models using Akaike's Information Criterion (AIC). Explanatory variables were removed one by one, and the model with fewer variables was tested against the more complex one. The reduced model was retained if the AIC was lower or if models were not significantly different. GLMMs on normally distributed data and residuals were fitted using an identity link function. The percent damage of cereal leaf beetle was $\arcsin [\operatorname{sqrt}(\mathrm{x} / 100)]$-transformed to achieve normality of residuals. Count data such as the abundance of crop herbivores or their natural enemies were analysed using a Poisson distribution with log link function. When overdispersion was detected models were fitted using 
a negative binomial distribution. All GLMM were run in the lme4 package (R, version 03.3.1, R Development Core Team (2013)).

All plant species included in the second step of the univariate GLMM were also used to build up multivariate models analysing relations between plants (explanatory variables) and the entire set of response variables. This approach allows a synthetic evaluation of potential plant species effects on herbivore regulation in order to analyse whether (and which) plant species have a positive effect on several regulation parameters at the same time. In order to decide whether a linear or a unimodal approach is better adapted to the data set, a Detrended Correspondence Analysis (DCA) was run on response variables (Canoco 5). The gradient length was quite small (1.3 SD for wheat, 1.6 SD for oilseed rape), advocating for a linear approach (ter Braak \& Smilauer, 2012). We finally used a Redundancy Analysis (RDA) as a method constraining explanatory variables in a linear model. The method also accounts for the different response variable types and units requiring an adjustment to zero mean and unit variance. Count data were additionally log-transformed and percentage values were $\arcsin [\operatorname{sqrt}(\mathrm{x} / 100)]$-transformed prior to analysis in order to homogenise variances and to obtain similar scales of response variables. The effect of explanatory values on response variables was evaluated by calculating the cumulative explained variation of all axes and using Pseudo-F statistics (ter Braak \& Smilauer, 2012).

\section{Results}

\section{Effects of plant species richness and plant groups}

We found altogether 260 plant species in the field margin survey of which 134 species occurred in the margins of both crops and 126 were specific to one of the crops. The vegetation can be characterised as disturbed Arrhenaterum elatius grassland with a dominance of the perennial grasses A. elatius, Elytrigia repens, Festuca arundinacea, Lolium perenne and Poa trivialis. 
The most common herbs were Galium aparine, Papaver rhoeas, Sinapis arvensis and Urtica dioica. Plant species richness was similar in both years and crops whereas the cover of entomophilous species was a little higher in the 2015 surveys and in oilseed rape margins (Fig. 2). There was huge variation in the cover of entomophilous species among fields within years and crops ranging from less than $1 \%$ to more than $50 \%$ (Fig. 3). The cover of crop-related plants was much higher in wheat field margins (Poaceae) than in oilseed rape margins (Brassicaceae). The dominant crop herbivores in wheat fields were cereal aphids and leaf beetles. Cereal aphid infestation was much higher in 2014 than in 2015 due to the more favourable weather conditions (warmer, less rainfall during peak infestation) but aphid parasitism was also lower in 2014 (Appendix A. Table 1A). Oilseed rape was mainly attacked by pollen beetles, cabbage aphids. Furthermore, stem and fruit weevils caused considerable damage in both years (Appendix A. Table 1B). In both crops (Tables 1 and 2), more significant effects of plant groups and species richness were observed close to the margins $(5 \mathrm{~m})$ than inside the fields $(50 \mathrm{~m})$. However, for five response variables (ladybug abundance in wheat, stem damage, aphid and hoverfly abundance, pollen beetle parasitism in oilseed rape), such effects occurred at a distance of 50 $\mathrm{m}$. Most of the significant relationships had a $P<0.05$ at $5 \mathrm{~m}$ and a $P<0.1$ only at $50 \mathrm{~m}$. In both crops, the cover of entomophilous species best explained crop herbivore regulation with predominantly positive relations to natural enemy abundance and negative relations to crop herbivore abundance and damage (Tables 1 and 2; Fig. 3). In winter wheat, plant species richness had only a weak influence on response variables and no significant effect was found for the cover of wild crop relatives. In oilseed rape, plant species richness and the cover of wild crop relatives showed some significant relationships with response variables. In particular, effects of wild Brassicaceae species on crop herbivore regulation were negative.

In winter wheat, the cover of entomophilous flowering plants was positively related to aphid parasitism and hoverfly abundance at $5 \mathrm{~m}$ and to ladybug abundance at $50 \mathrm{~m}$ suggesting a better 
control of aphids (Table 1, Fig 3A). However, aphid abundance was not significantly related to any of the tested plant groups. In oilseed rape, the cover of entomophilous flowering plants was negatively related to aphid abundance at $5 \mathrm{~m}$ and to stem damage at $50 \mathrm{~m}$. The correlation to pollen beetle larvae parasitism at $5 \mathrm{~m}$ and to hoverfly abundance at $50 \mathrm{~m}$ was negative (Fig. 3B). Relationships were significant at $5 \mathrm{~m}$ but only marginally significant at $50 \mathrm{~m}$. Stem damage and pollen beetle larvae increased with the cover of wild Brassicaceae species and pollen beetle parasitism decreased (all at $5 \mathrm{~m}$ ). Plant species richness was positively related to leaf beetle damage $(5 \mathrm{~m})$ in wheat, and to aphid abundance and pollen beetle parasitism in oilseed rape (50 m, Appendix A. Fig. 1).

\section{Identification of plant species related to herbivore regulation}

Since the cover of entomophilous flowering plants was best related to herbivore regulation in both crops, we tested which species within this group contributed most to regulation. Wheat and oilseed rape margins shared five species among the most frequently surveyed ten species in total. Papaver rhoeas and Vicia sativa cover significantly influenced response variables in both crops (Table 3). However, both species showed positive and negative effects on crop herbivore regulation. $P$. rhoeas flower cover was positively related to hoverfly abundance in wheat and negatively to aphid abundance but also negatively to hoverfly abundance and pollen beetle parasitism in oilseed rape. $V$. sativa cover was negatively related to aphid parasitism in wheat but positively to pollen beetle parasitism. Positive (hoverflies) and negative effects (ladybugs) were also observed for Galium mollugo in wheat. Leucanthemum vulgare had a strong positive effect on regulation in wheat (highly significant effect on ladybugs and aphid parasitism) while Sonchus asper cover was positively related to regulation in oilseed rape (negatively with aphid abundance, positively with pollen beetle parasitism).

The multivariate analyses testing effects on all response variables did not clearly identify plant species that have a general positive influence on the regulation of crop herbivores. Significant 
relationships obtained by the univariate analysis (Table 3) were also visible in the RDA biplots (Fig. 4). However, the RDA did not always separate explanatory variables that were positively from those that were negatively related to crop herbivore regulation. For example, in winter wheat aphid and ladybug abundance as well as hoverfly and leaf beetle abundances occurred together in the explanatory - response variable biplot. At a distance of $5 \mathrm{~m}$, plant species as explanatory variables accounted for $30 \%$ of variation in wheat (Pseudo $\mathrm{F}=0.9, \mathrm{P}=0.578$ ) and for $38 \%$ in oilseed rape (Pseudo $\mathrm{F}=1.3, \mathrm{P}=0.078$ ). At a distance of $50 \mathrm{~m}$ (biplots not shown) these values were $29 \%$ for winter wheat (Pseudo $\mathrm{F}=0.9, \mathrm{P}=0.710$ ) and $35 \%$ for oilseed rape (Pseudo $\mathrm{F}=1.1, \mathrm{P}=0.202$ ). Due to the better model fit, we focus in the following paragraph on the $5 \mathrm{~m}$ data.

In winter wheat, a group of three species increased aphid parasitism and reduced aphid abundance (but also ladybug abundance) at the same time: Galium mollugo, Trifolium pratense and, to a lesser degree, Leucanthemum vulgare. Papaver rhoeas was positively related to hoverfly abundance and negatively to leaf beetle damage (but also to ladybugs). In oilseed rape, the overlap of response variables representing crop herbivory with those representing natural enemies was even stronger than in winter wheat. A group comprising Veronica persica, Galium aparine, Silene latifolia and Geranium molle favoured aphid parasitism and was negatively correlated with pollen beetle abundance (larvae and adults). The influence on parasitoids and pollen beetle parasitism was, however, negative. Papaver rhoeas correlated negatively to three major crop herbivores: pollen beetles (larvae), stem weevils (damage) and aphids.

\section{Discussion}

\section{Plant species richness and plant groups}

In field margins of both crops, we found a high plant species richness but large variation in plant species composition between fields. The total number of plant species was as high as in a 
previous study on field margins of the same region but bordering brassicacean vegetables (Bischoff et al., 2016). Margin vegetation is often bordered by different habitats such as wetlands, woodlands or meadows but also by the arable fields with different plant communities (Bischoff et al. 2016, Cordeau, Petit, Reboud, \& Chauvel, 2012). This ecotone character of margins explains the high species richness compared to adjacent non-ecotone habitats.

Plant species richness, taxonomic and functional groups of field margin vegetation significantly influenced insect communities (natural enemies, crop herbivores, parasitism and damages) in the adjacent fields covering the typical variety of cultural practices in the study region. In agreement with (Schaffers et al., 2008), the results showed that the local plant community is an important predictor of arthropod communities although our study was limited to crop herbivores and natural enemies. Fewer significant relationships were found at a distance of $50 \mathrm{~m}$ than close to the margins at $5 \mathrm{~m}$. Such a decline of vegetation effects on arthropods and on crop herbivore regulation was also found in other studies (Collins, Boatman, Wilcox, Holland, \& Chaney, 2002; Tylianakis et al., 2004). It may be explained by the energetic costs of movements and the relative attractiveness of margins preventing natural enemies from moving into the field (Heimpel \& Jervis, 2005; Wanner, Gu, Hattendorf, Günther, \& Dorn, 2006). However, some correlations only occurred at a distance of $50 \mathrm{~m}$. Indirect effects, such as competition with other natural enemy groups, resulting in a lower availability of prey, may have contributed to the absence of significant effects close to the field margin.

Entomophilous plant species flowering at the survey dates showed the strongest correlations with the tested response variables. Relations to crop herbivores and damage were negative and those to natural enemy abundance or attack (parasitism) were generally positive except for pollen beetle parasitism. These results confirmed the findings of Bischoff et al. (2016) obtained for phytometer crop plants placed into the field margins. The present study showed that positive effects of entomophilous plant species on the regulation of crop herbivores can also be detected 
within the crop fields. In wheat fields, positive relationships were found between entomophilous plant cover and aphid parasitism and the abundance of two major groups of aphid enemies, hoverflies and ladybugs. It is well known that adult hoverflies rely on nectar resources (Fiedler, Landis, \& Wratten, 2008; Wäckers, 2004). A better resource provisioning resulting in higher adult performance increases egg deposition and density of aphidophagous larvae in the field (Laubertie, Wratten, \& Hemptinne, 2012). Recently, similar results were obtained for parasitoids also feeding on nectar. Adult longevity and parasitism rates were found to depend on nectar provided by entomophilous plant species (Araj \& Wratten, 2015; Géneau, Wäckers, Luka, Daniel, \& Balmer, 2012; Jamont, Dubois-Pot, \& Jaloux, 2014; Pollier et al., 2016). In contrast to hoverflies and parasitoids, adult ladybugs are predominantly predators. However, gut content analyses and observational studies have shown that adult and larval ladybugs also consume nectar and pollen contributing to fitness and predation performance (Ricci, Ponti, \& Pires, 2005; Triltsch, 1999). In oilseed rape fields, entomophilous plant cover had a negative influence on herbivory (aphid abundance, weevil stem damage) but not on predators and parasitism. Pollen beetle parasitism and hoverfly abundance (although only at $P<0.1$ ) were even negatively related to entomophilous plant cover. It seems quite likely that the observed reduction in herbivory was still the result of a positive regulatory effect by natural enemies but that higher predation occurred before survey dates or that generalist natural enemies not analysed in this study such as ground beetles regulated herbivores (Collins et al., 2002; Valantin-Morison et al., 2007).

Taxonomically related plant species had no influence on herbivore regulation in wheat but increased herbivore attack and damage in oilseed rape. Pollen beetles and stem weevils may have been attracted by wild Brassicaceae species of the field margin switching afterwards to the crop plants. Such an associational susceptibility was also observed in previous studies on different brassicacean crops (Bischoff et al., 2016; Le Guigo et al., 2012). In wheat, 
associational resistance due to a higher attractiveness of wild relatives (Poaceae grasses) may have counteracted the spill over of herbivores into the field (Barbosa et al., 2009; Le Guigo et al., 2012).

Against our expectations, we found few and predominantly negative correlations between plant species richness and crop herbivore regulation. In most studies of a recent meta-analysis, predators responded positively to plant diversity, and specialist herbivores showed a corresponding negative response (Dassou \& Tixier, 2016). Niche complementarity may explain such a positive relationship. Flower visiting natural enemies of crop herbivores often use different plant species as a resource (Heimpel \& Jervis, 2005; Stang, Klinkhamer, \& Van Der Meijden, 2006) and higher plant species richness results in a higher natural enemy diversity increasing the regulation potential (Campbell, Biesmeijer, Varma, \& Wäckers, 2012). In our study, the quantity of flowering entomophilous plants clearly overruled diversity effects in a multifactorial analysis.

\section{Identification of plant species related to herbivore regulation}

Within entomophilous flowering plants, several species could be identified that were linked to a better herbivore regulation such as $L$. vulgare in wheat and S. asper in oilseed rape. P. rhoeas (both crops) and G. mollugo showed positive and negative effects on regulation suggesting negative interactions between different natural enemy groups (competition). Relationships with plant species were often specific for just one or two herbivore or natural enemy groups. Positive effects of $L$. vulgare on natural enemies have already been shown in previous studies. A screening experiment testing 52 plant species in monospecific stands close to winter wheat revealed a good overall score of the species hosting generalist and specialist enemies of wheat herbivores (Frei \& Manhart, 1992). A recent study comparing the resource provisioning for pollinators showed that this species produces high pollen and nectar sugar quantities (Hicks et 
al., 2016). Different Sonchus species are also highly nectar rewarding, and in particular Sonchus asper considerably contributed to the total nectar production of the tested plant community (Hicks et al., 2016). So there is some evidence that positive interactions between crop herbivore regulation and flowering plants are mediated by the provisioning of floral resources.

The multivariate analysis allowed drawing more general conclusions on plant species effects in a plant and animal community context. In winter wheat, positive effects of three already mentioned plant species ( $P$. rhoeas, G. mollugo, L. vulgare) on several response variables linked to aphid regulation (aphid and hoverfly abundance, aphid parasitism) were identified in RDA biplots. Additionally, Trifolium pratense was related to higher aphid parasitism rate and lower aphid number. Focussing on damage and crop herbivore abundance as response variables closely linked to crop yield, some general trends were also visible in oilseed rape. P. rhoeas cover was negatively related to aphid infestation and stem damage, and a group of four species (V. persica, G. aparine, S. latifolia, G. molle) negatively to pollen beetle (adult and larvae) abundance and pod damage. As L. vulgare, S. latifolia is known to produce high amounts of nectar and pollen that may attract natural enemies of pollen beetles and pod weevils whereas the other three plant species do not seem to be very attractive to insects depending on floral resources (Frei \& Manhart, 1992, Hicks et al. 2016).

However, natural enemies and crop herbivores or damage were not always separated in RDA biplots limiting conclusions on plants that may improve the general level of regulation over several herbivores. In winter wheat, aphid parasitism and leaf beetle damage as well as aphid and hoverfly abundance occurred closely together. In oilseed rape, a similar proximity was observed for pollen beetle larvae and pollen beetle parasitism, for aphids and aphid parasitism and again for aphids and ladybugs. These correlations complicate the interpretation of results, in particular the evaluation of causality. A higher abundance of natural enemies may result from 
better resource provisioning by the adjacent vegetation but also from a higher prey (crop herbivore) density.

\section{Conclusions}

Our study demonstrated the importance of entomophilous species that flower at peak infestation of crop herbivores, suggesting that the amount of floral resources is a key factor in herbivore regulation. Contrary to previous studies, this effect could be demonstrated inside crop fields and was not limited to field margins (Bischoff et al., 2016; Frei \& Manhart, 1992; Sivinski et al., 2011). In oilseed rape, significant results were obtained down to the trophic level of crop plants and their herbivores whereas in winter wheat effects were limited to natural enemies. Within the group of entomophilous plants, we identified individual species that improved herbivore regulation but in most cases effects were limited to one or two response variables. This result highlights the importance of plant diversity offering complementary floral traits although relationships between total species richness and herbivore regulation were relatively weak or negative.

A correlative approach relating vegetation characteristics and herbivore regulation is useful to identify candidate species for designing seed mixtures improving regulation services. Contrary to classical wildflower strip studies using monospecific stands or early successional stages of sown mixtures (Haaland et al., 2011; Sivinski et al., 2011; Tschumi et al., 2015), it allows testing plant species and group effects in a late-successional, semi-natural community context. Our study showed that spontaneous field margins rich in flowering entomophilous species provide an important biocontrol service without expensive sowing of seed mixtures. Likewise, Denys and Tscharntke (2002) found that arthropod species richness and predator-prey ratios were as high in spontaneous field margin vegetation as in sown wildflower strips. The high regulation potential of spontaneous field margin vegetation needs to be better supported in agri- 
environmental schemes currently focussing on wildflower strips (Haaland et al., 2011). Therefore, financial support should be linked to an appropriate management protecting margins from early cutting (until peak infestation of crop herbivores), shrub encroachment, fertiliser input and pesticide drift.

\section{Acknowledgements}

We thank E. Chenu for her technical assistance and T. Sollet, A. Saphore and S. Le Barazer for their help in the field. We also thank all farmers who participated in our study for hospitality and information provided. The project was funded by the French National Research Agency (ANR, "PEERLESS") and the chair Ecologically Intensive Agriculture (AEI).

\section{Appendix A. Supplementary data}

Supplementary data associated with this article can be found, in the online version, at XXXXX." 


\section{References}

Araj, S.-E., \& Wratten, S. D. (2015). Comparing existing weeds and commonly used insectary plants as floral resources for a parasitoid. Biological Control, 81, 15-20.

Balmer, O., Géneau, C. E., Belz, E., Weishaupt, B., Förderer, G., Moos, S., ... Luka, H. (2014). Wildflower companion plants increase pest parasitation and yield in cabbage fields: Experimental demonstration and call for caution. Biological Control, 76, 19-27.

Balmer, O., Pfiffner, L., Schied, J., Willareth, M., Leimgruber, A., Luka, H., \& Traugott, M. (2013). Noncrop flowering plants restore top-down herbivore control in agricultural fields. Ecology and Evolution, 3(8), 2634-2646.

Balvanera, P., Pfisterer, A. B., Buchmann, N., He, J.-S., Nakashizuka, T., Raffaelli, D., \& Schmid, B. (2006). Quantifying the evidence for biodiversity effects on ecosystem functioning and services. Ecology Letters, 9(10), 1146-1156.

Balzan, M. V., Bocci, G., \& Moonen, A.-C. (2014). Augmenting flower trait diversity in wildflower strips to optimise the conservation of arthropod functional groups for multiple agroecosystem services. Journal of insect conservation, 18(4), 713-728.

Barbosa, P., Hines, J., Kaplan, I., Martinson, H., Szczepaniec, A., \& Szendrei, Z. (2009). Associational Resistance and Associational Susceptibility: Having Right or Wrong Neighbors. Annual Review of Ecology, Evolution, and Systematics, 40(1), 1-20.

Begg, G. S., Cook, S. M., Dye, R., Ferrante, M., Franck, P., Lavigne, C., ... Birch, A. N. E. (2017). A functional overview of conservation biological control. Crop Protection, 97(Supplement C), 145-158.

Bianchi, F. J. J. A., Booij, C. J. H., \& Tscharntke, T. (2006). Sustainable pest regulation in agricultural landscapes: a review on landscape composition, biodiversity and natural pest control. Proceedings of the Royal Society of London B: Biological Sciences, 273(1595), 1715-1727. 
Billeter, R., Liira, J., Bailey, D., Bugter, R., Arens, P., Augenstein, I., Edwards, P. j. (2008). Indicators for biodiversity in agricultural landscapes: a pan-European study. Journal of Applied Ecology, 45(1), 141-150.

Bischoff, A., Pollier, A., Lamarre, E., Salvadori, O., Cortesero, A.-M., Le Ralec, A., Jaloux, B. (2016). Effects of spontaneous field margin vegetation and surrounding landscape on Brassica oleracea crop herbivory. Agriculture, Ecosystems \& Environment, 223, 135143.

Blaauw, B. R., \& Isaacs, R. (2012). Larger wildflower plantings increase natural enemy density, diversity, and biological control of sentinel prey, without increasing herbivore density. Ecological Entomology, 37(5), 386-394.

Braun-Blanquet, J. (1964). Pflansensoziologie. Third edition. Springer, Vienna, Austria.

Campbell, A. J., Biesmeijer, J. C., Varma, V., \& Wäckers, F. L. (2012). Realising multiple ecosystem services based on the response of three beneficial insect groups to floral traits and trait diversity. Basic and Applied Ecology, 13(4), 363-370.

Chaplin-Kramer, R., O’Rourke, M. E., Blitzer, E. J., \& Kremen, C. (2011). A meta-analysis of crop pest and natural enemy response to landscape complexity. Ecology Letters, 14(9), 922-932.

Collins, K. L., Boatman, N. D., Wilcox, A., Holland, J. M., \& Chaney, K. (2002). Influence of beetle banks on cereal aphid predation in winter wheat. Agriculture, Ecosystems \& Environment, 93(1-3), 337-350.

Cordeau, S., Petit, S., Reboud, X., \& Chauvel, B. (2012). Sown grass strips harbour high weed diversity but decrease weed richness in adjacent crops. Weed Research, 52(1), 88-97.

Daamgard, C. (2014). Estimating mean plant cover from different types of cover data: a coherent statistical framework. Ecosphere, 5(2), 1-7. 
Dassou, A. G., \& Tixier, P. (2016). Response of pest control by generalist predators to localscale plant diversity: a meta-analysis. Ecology and Evolution, 6(4), 1143-1153.

Denys, C., \& Tscharntke, T. (2002). Plant-insect communities and predator-prey ratios in field margin strips, adjacent crop fields, and fallows. Oecologia, 130(2), 315-324.

Diehl, E., Mader, V. L., Wolters, V., \& Birkhofer, K. (2013). Management intensity and vegetation complexity affect web-building spiders and their prey. Oecologia, 173(2), $579-589$.

Fiedler, A. K., Landis, D. A., \& Wratten, S. D. (2008). Maximizing ecosystem services from conservation biological control: The role of habitat management. Biological Control, $45(2), 254-271$.

Frei, G., \& Manhart, C. (1992). Nützlinge und Schädlinge an künstlich angelegten Ackerkrautstreifen in Getreidefeldern. Haupt.

Géneau, C. E., Wäckers, F. L., Luka, H., Daniel, C., \& Balmer, O. (2012). Selective flowers to enhance biological control of cabbage pests by parasitoids. Basic and Applied Ecology, 13(1), 85-93.

Griffiths, G. J. K., Holland, J. M., Bailey, A., \& Thomas, M. B. (2008). Efficacy and economics of shelter habitats for conservation biological control. Biological Control, 45(2), 200209.

Haaland, C., Naisbit, R. E., \& Bersier, L.-F. (2011). Sown wildflower strips for insect conservation: a review. Insect Conservation and Diversity, 4(1), 60-80.

Heimpel, G. E., \& Jervis, M. A. (2005). Does floral nectar improve biological control by parasitoids. Cambridge University Press.

Hicks, D. M., Ouvrard, P., Baldock, K. C. R., Baude, M., Goddard, M. A., Kunin, W. E., ... Stone, G. N. (2016). Food for Pollinators: Quantifying the Nectar and Pollen Resources of Urban Flower Meadows. PLOS ONE, 11(6), e0158117. 
Jamont, M., Dubois-Pot, C., \& Jaloux, B. (2014). Nectar provisioning close to host patches increases parasitoid recruitment, retention and host parasitism. Basic and Applied Ecology, 15(2), 151-160.

Klotz, S., Kühn, I., \& Durka, W. (2002). Database on Biological and Ecological Traits on the Flora of Germany - Schriftenreihe für Vegetationskunde 38. Bonn: Bundesamt für Naturschutz.

Landis, D. A. (2017). Designing agricultural landscapes for biodiversity-based ecosystem services. Basic and Applied Ecology, 18(Supplement C), 1-12.

Laubertie, E. A., Wratten, S. D., \& Hemptinne, J.-L. (2012). The contribution of potential beneficial insectary plant species to adult hoverfly (Diptera: Syrphidae) fitness. Biological Control, 61(1), 1-6.

Le Guigo, P., Rolier, A., \& Le Corff, J. (2012). Plant neighborhood influences colonization of Brassicaceae by specialist and generalist aphids. Oecologia, 169(3), 753-761.

Lee, J. C., Menalled, F. D., \& Landis, D. A. (2001). Refuge habitats modify impact of insecticide disturbance on carabid beetle communities. Journal of Applied Ecology, $38(2), 472-483$.

Letourneau, D. K., Armbrecht, I., Rivera, B. S., Lerma, J. M., Carmona, E. J., Daza, M. C., ... Trujillo, A. R. (2011). Does plant diversity benefit agroecosystems? A synthetic review. Ecological Applications, 21(1), 9-21.

MacLeod, A., Wratten, S. D., Sotherton, N. W., \& Thomas, M. B. (2004). 'Beetle banks' as refuges for beneficial arthropods in farmland: long-term changes in predator communities and habitat. Agricultural and Forest Entomology, 6(2), 147-154.

Meek, B., Loxton, D., Sparks, T., Pywell, R., Pickett, H., \& Nowakowski, M. (2002). The effect of arable field margin composition on invertebrate biodiversity. Biological Conservation, 106(2), 259-271. 
Pollier, A., Dosdat, S., Tricault, Y., Bischoff, A., Plantegenest, M., \& Jaloux, B. (2016). Using the stable isotope marker $13 \mathrm{C}$ to study extrafloral nectar uptake by parasitoids under controlled conditions and in the field. Entomologia Experimentalis et Applicata, 161(2), $131-140$.

Ricci, C., Ponti, L., \& Pires, A. (2005). Migratory flight and pre-diapause feeding of Coccinella septempunctata (Coleoptera) adults in agricultural and mountain eco-systems of Central Italy. European Journal of Entomology, 102(3), 531.

Schaffers, A. P., Raemakers, I. P., Sýkora, K. V., \& ter Braak, C. J. F. (2008). Arthropod Assemblages Are Best Predicted by Plant Species Composition. Ecology, 89(3), 782794.

Sivinski, J., Wahl, D., Holler, T., Dobai, S. A., \& Sivinski, R. (2011). Conserving natural enemies with flowering plants: Estimating floral attractiveness to parasitic Hymenoptera and attraction's relationship to flower and plant morphology. Biological Control, 58(3), 208-214.

Stang, M., Klinkhamer, P. G. L., \& Van Der Meijden, E. (2006). Size constraints and flower abundance determine the number of interactions in a plant-flower visitor web. Oikos, 112(1), 111-121.

ter Braak, C. J. F., \& Smilauer, P. (2012). Canoco reference manual and user's guide: software for ordination, version 5.0. Ithaca USA: Microcomputer Power.

Triltsch, H. (1999). Food remains in the guts of Coccinella septempunctata (Coleoptera: Coccinellidae) adults and larvae. European Journal of Entomology, 96, 355-364.

Tscharntke, T., Karp, D. S., Chaplin-Kramer, R., Batáry, P., DeClerck, F., Gratton, C., ... Zhang, W. (2016). When natural habitat fails to enhance biological pest control - Five hypotheses. Biological Conservation, 204, Part B, 449-458. 
Tscharntke, T., Batáry, P., \& Dormann, C. F. (2011). Set-aside management: How do succession, sowing patterns and landscape context affect biodiversity? Agriculture, Ecosystems \& Environment, 143(1), 37-44.

Tschumi, M., Albrecht, M., Entling, M. H., \& Jacot, K. (2015). High effectiveness of tailored flower strips in reducing pests and crop plant damage. Proceedings of the Royal Society B: Biological Sciences, 282(1814), 20151369.

Tylianakis, J. M., Didham, R. K., \& Wratten, S. D. (2004). Improved fitness of aphid parasitoids receiving resource subsidies. Ecology, 85(3), 658-666.

Valantin-Morison, M., Meynard, J.-M., \& Doré, T. (2007). Effects of crop management and surrounding field environment on insect incidence in organic winter oilseed rape (Brassica napus L.). Crop Protection, 26(8), 1108-1120.

Veres, A., Petit, S., Conord, C., \& Lavigne, C. (2013). Does landscape composition affect pest abundance and their control by natural enemies? A review. Agriculture, Ecosystems \& Environment, 166, 110-117.

Wäckers, F. L., \& van Rijn, P. C. J. (2012). Pick and Mix: Selecting Flowering Plants to Meet the Requirements of Target Biological Control Insects. In G. M. Gurr, S. D. Wratten, W. E. Snyder, \& D. M. Y. Read (Eds.), Biodiversity and Insect Pests (pp. 139-165). Chichester, UK: John Wiley \& Sons, Ltd.

Wäckers, F. (2004). Assessing the suitability of flowering herbs as parasitoid food sources: flower attractiveness and nectar accessibility. Biological Control, 29(3), 307-314.

Wanner, H., Gu, H., Hattendorf, B., GüNther, D., \& Dorn, S. (2006). Using the stable isotope marker ${ }^{44} \mathrm{Ca}$ to study dispersal and host-foraging activity in parasitoids: Stable isotope marking of parasitoids. Journal of Applied Ecology, 43(5), 1031-1039. 
Winkler, K., Wäckers, F. L., Kaufman, L. V., Larraz, V., \& van Lenteren, J. C. (2009). Nectar exploitation by herbivores and their parasitoids is a function of flower species and relative humidity. Biological Control, 50(3), 299-306.

Woltz, J. M., Isaacs, R., \& Landis, D. A. (2012). Landscape structure and habitat management differentially influence insect natural enemies in an agricultural landscape. Agriculture, Ecosystems \& Environment, 152, 40-49. 


\section{Figure legends}

Fig. 1. (A) Geographical position of the study area in France, (B) the analysed fields within the study area and (C) the survey design.

Fig. 2. Total species richness (top) and cover of plant groups (bottom; CEFP: entomophilous flowering plants, CPO: Poaceae, CBR: Brassicaceae) measured in field margins $\left(75 \mathrm{~m}^{2}\right)$ of (A) wheat and (B) oilseed rape fields in 2014 (black bars) and 2015 (grey bars); means \pm SD.

Fig. 3. Relationships between the cover of flowering entomophilous plants and significantly affected response variables $(\mathrm{P}<0.1)$ using parameter estimates of Generalized Linear Mixed Models (GLMM) for (A) wheat and (B) oilseed rape.

Fig. 4. Ordination biplots (first and second axis) of Redundancy Analysis (RDA) showing relations between explanatory (entomophilous plant species) and response variables (crop herbivores, crop damage and natural enemies) for (A) wheat and (B) oilseed rape. 


\section{Figures}

Figure 1:

(A)

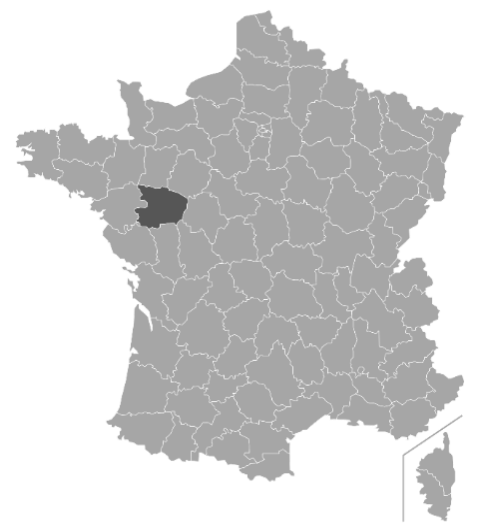

(C)

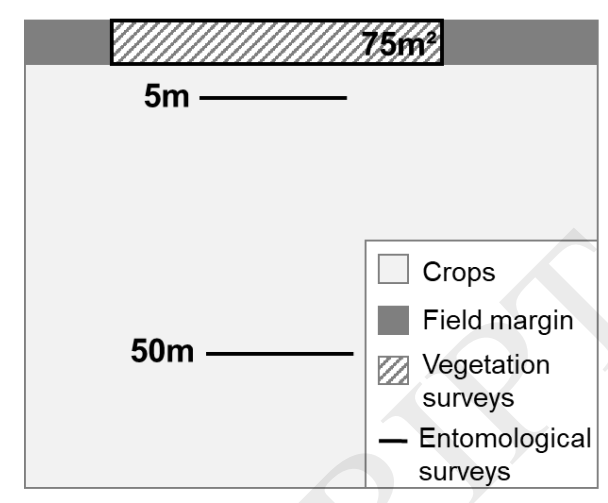

(B)
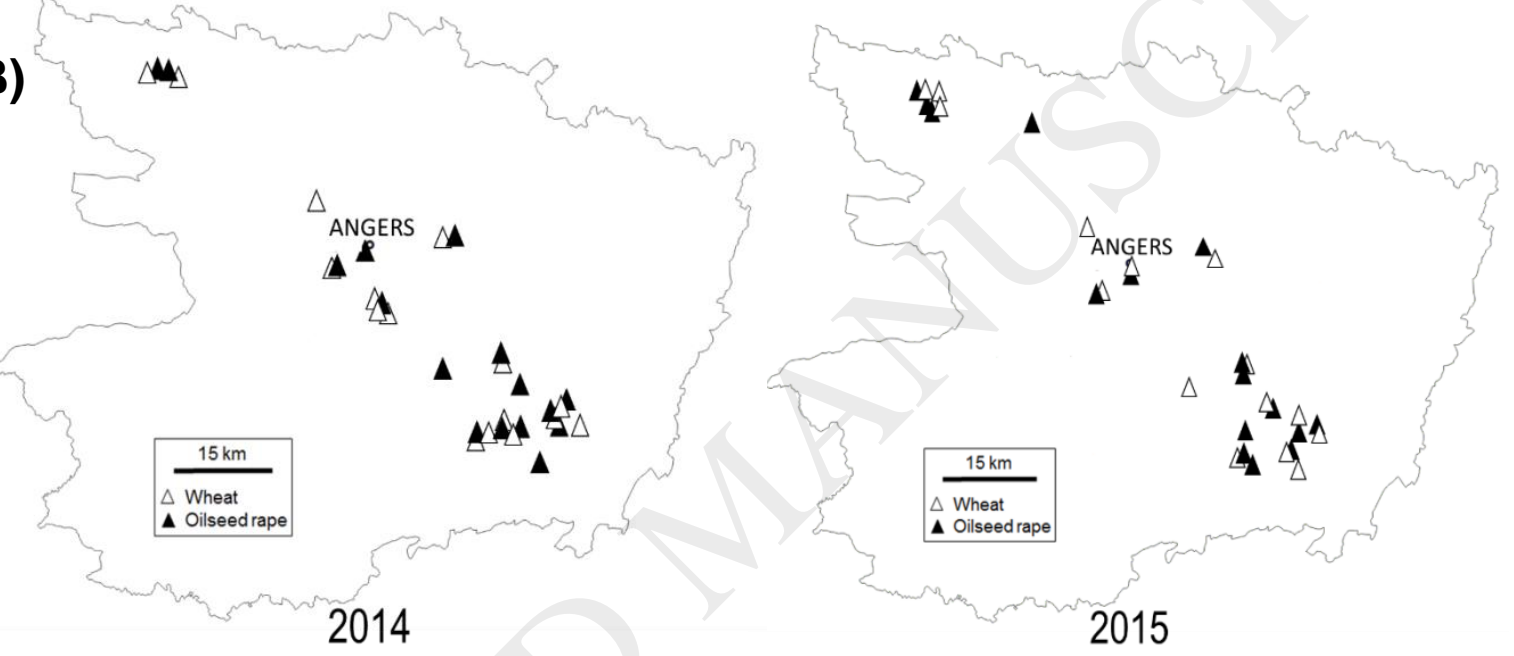
Figure 2:

\section{(A) Wheat}
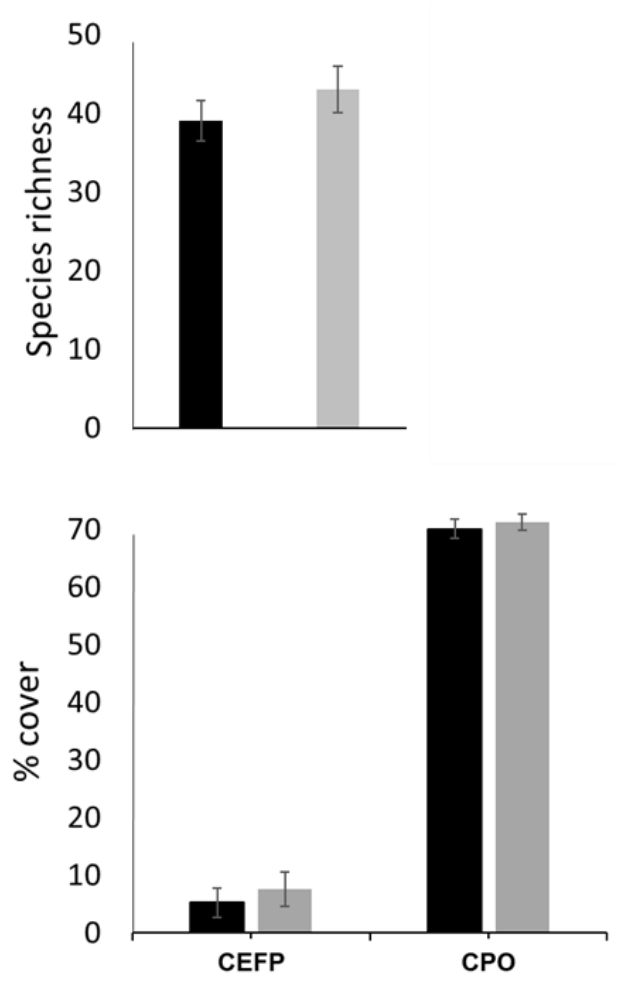

(B) Oilseed rape
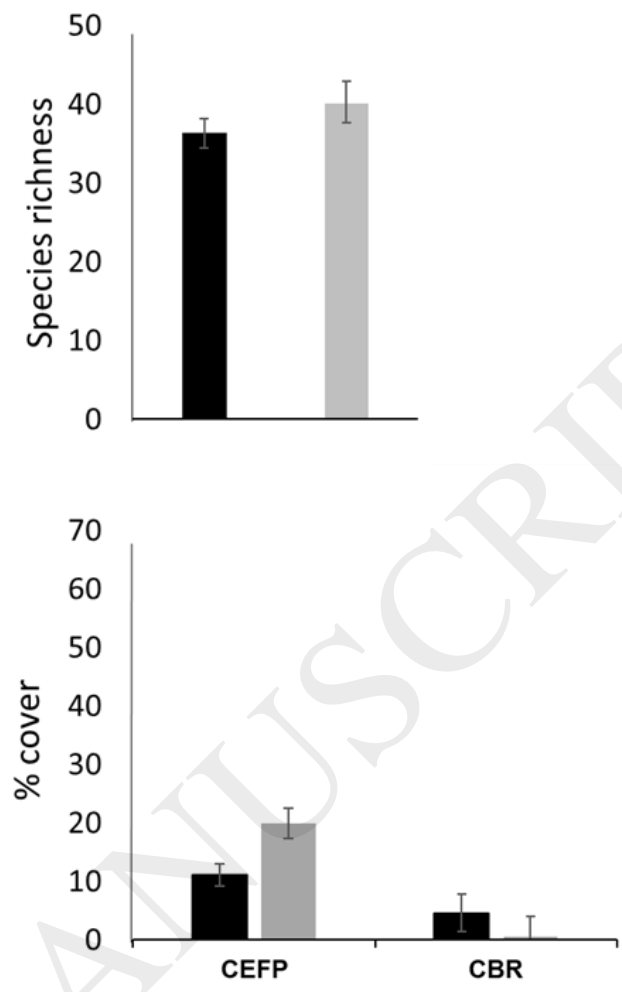
Figure 3:

(A) Wheat
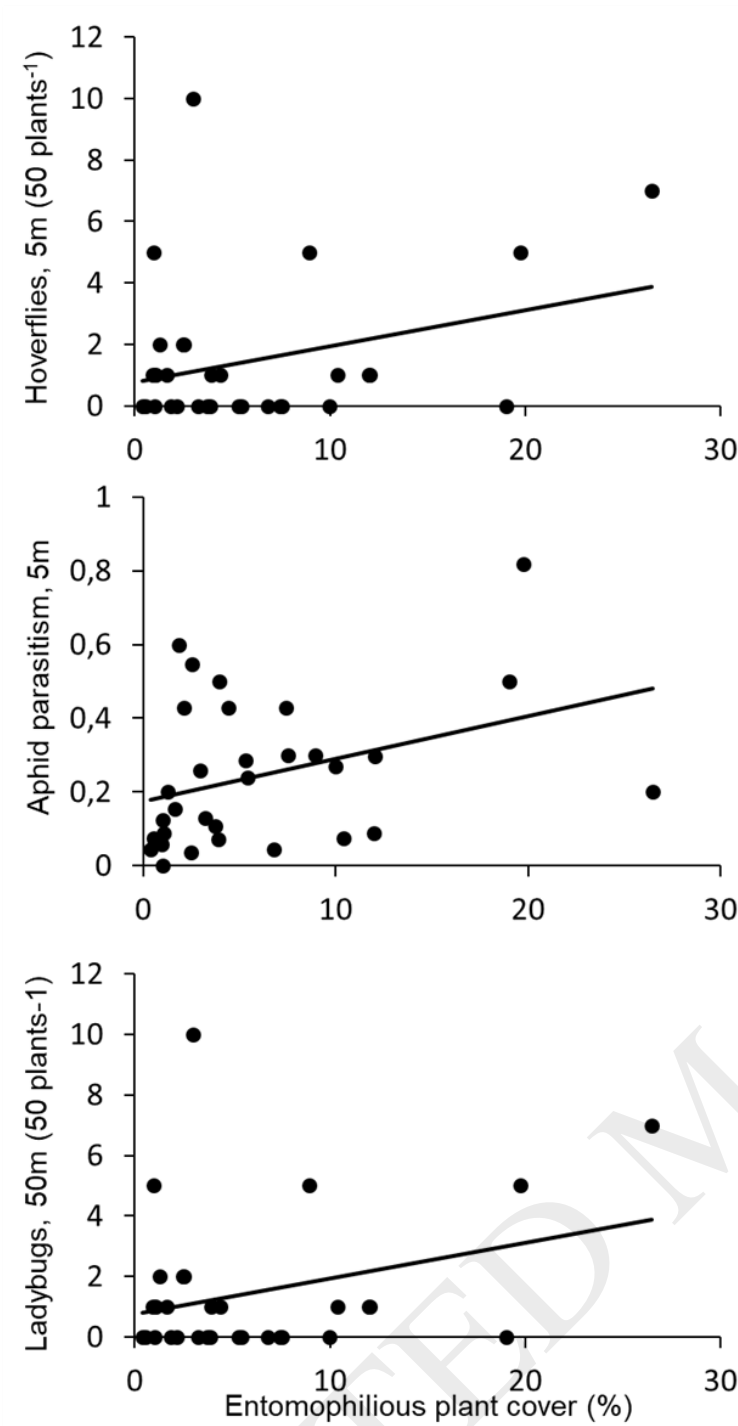

(B) Oilseed rape
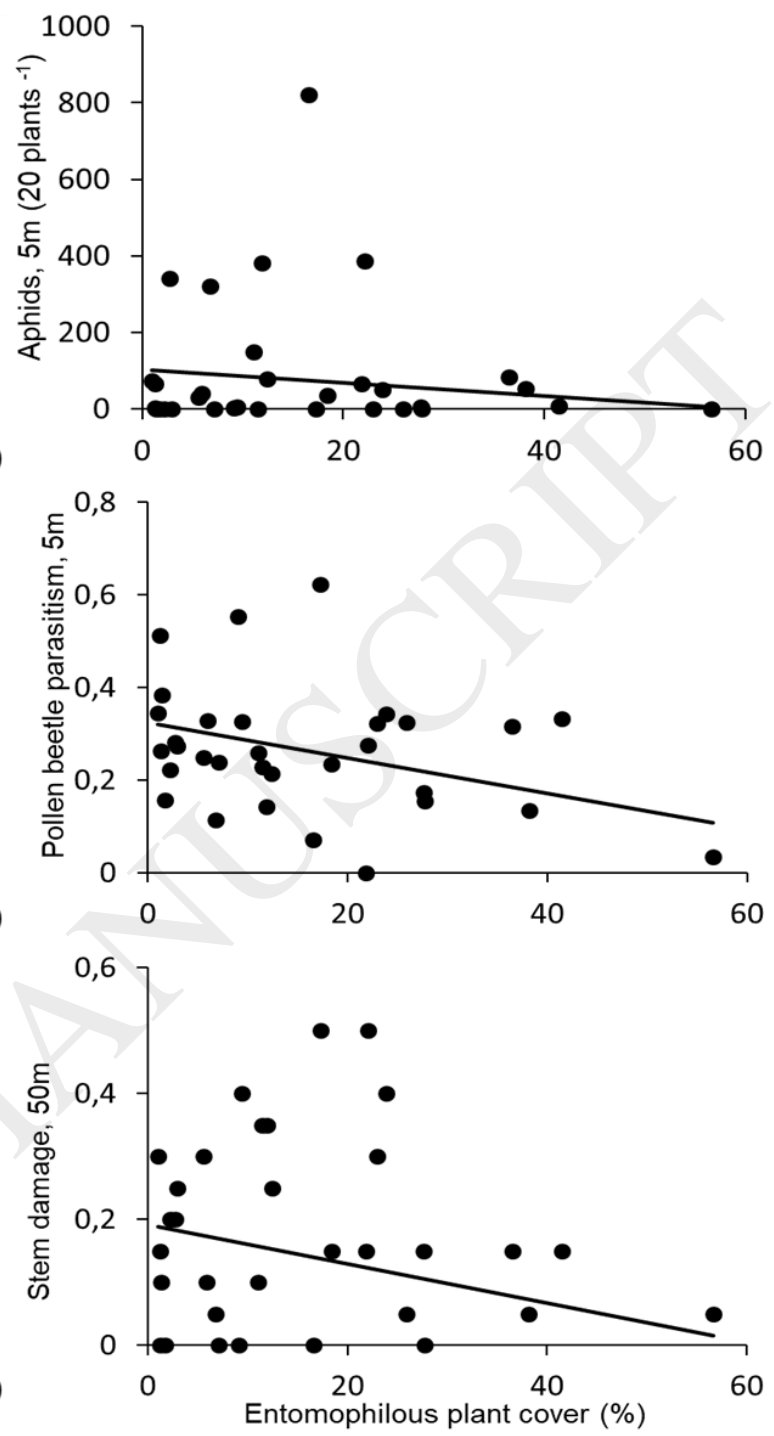
Figure 4:

\section{(A) Wheat}

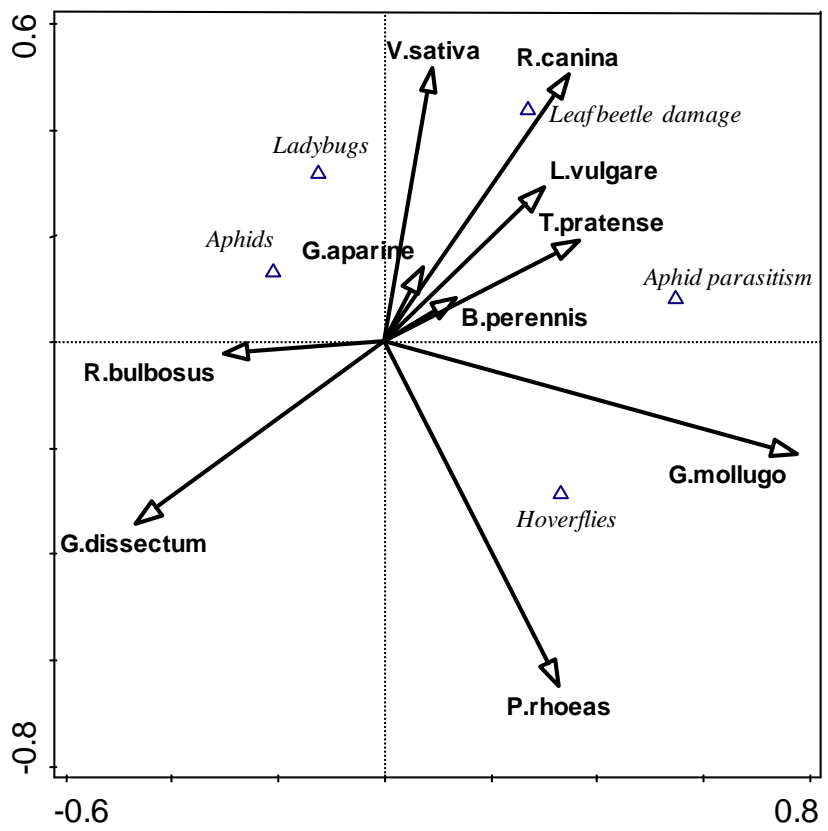

(B) Oilseed rape

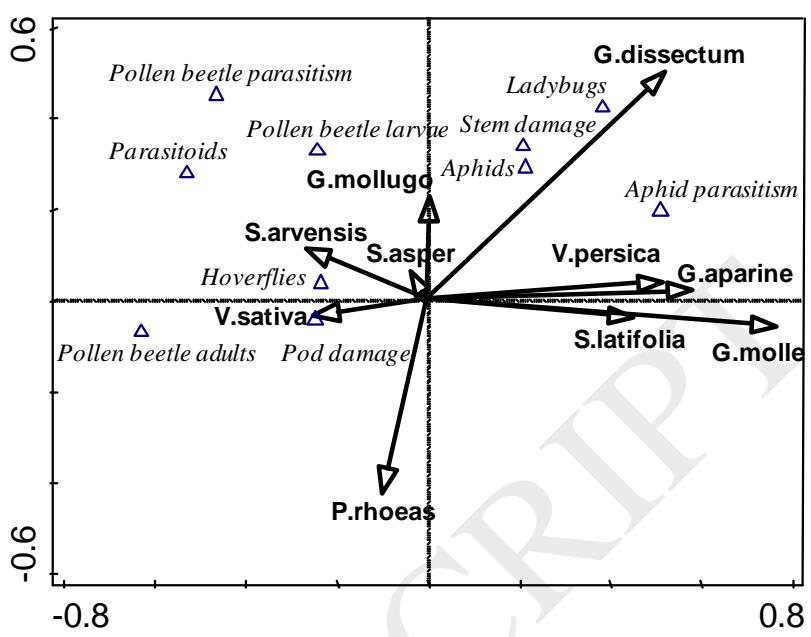




\section{Tables}

Table 1. Results on wheat fields: relations between plant species composition (species richness, entomophilous flowering plants, Poaceae) of field margins as explanatory variables and crop herbivore abundance/damage and predator abundance/parasitism at a distance of $5 \mathrm{~m}$ and $50 \mathrm{~m}$ from field margins. GLMM estimates and significance levels of explanatory variables are presented for the best model (lowest AIC). -: not retained by AIC, $+\mathrm{P}<0.1 \mathrm{P}<0.05 * \mathrm{P}<0.01 * *$ $\mathrm{P}<0.001 * * *$, ns: not significant.

\begin{tabular}{|c|c|c|c|c|}
\hline Distance: 5 m & $\begin{array}{l}\text { Plant species } \\
\text { richness }\end{array}$ & $\begin{array}{l}\text { Entomophilous } \\
\text { plant cover }\end{array}$ & $\begin{array}{l}\text { Poaceae } \\
\text { cover }\end{array}$ & Family \\
\hline \multicolumn{5}{|l|}{ Herbivores and damage } \\
\hline Aphids & - & & - & Gaussian \\
\hline Leaf beetle larvae & ns & & ns & Neg binomial \\
\hline Leaf beetle larvae damage & $0.002^{*}$ & & ns & Gaussian \\
\hline \multicolumn{5}{|c|}{ Predators and parasitism } \\
\hline Ladybugs & - & & ns & Neg binomial \\
\hline Hoverflies & ns & $.076^{*}$ & - & Neg binomial \\
\hline Aphid parasitism & 0 & $.007+$ & - & Gaussian \\
\hline Distance: $\mathbf{5 0 ~} \mathbf{m}$ & $\begin{array}{l}\text { Plant species } \\
\text { richness }\end{array}$ & $\begin{array}{l}\text { Entomophilous } \\
\text { plant cover }\end{array}$ & $\begin{array}{l}\text { Poaceae } \\
\text { cover }\end{array}$ & Family \\
\hline \multicolumn{5}{|l|}{ Herbivores and damage } \\
\hline Aphids & ns & & - & Neg binomial \\
\hline Leaf beetle larvae & ns & & - & Neg binomial \\
\hline Leaf beetle larvae damage & ns & & ns & Gaussian \\
\hline \multicolumn{5}{|c|}{ Predators and parasitism } \\
\hline Ladybugs & - & $.068^{\star * *}$ & ns & Poisson \\
\hline Hoverflies & ns & & ns & Neg binomial \\
\hline Aphid parasitism & ns & & - & Gaussian \\
\hline
\end{tabular}


Table 2. Results on oilseed rape fields: relationships between plant species composition (species richness, entomophilous flowering plants, Brassicaceae) of field margins as explanatory variables and crop herbivore abundance/damage and predator abundance/parasitism at distances of $5 \mathrm{~m}$ and $50 \mathrm{~m}$ from field margins as response variables. GLMM estimates and significance levels of explanatory variables are presented for the best model (lowest AIC). -: not retained by AIC, $+\mathrm{P}<0.1 \mathrm{P}<0.05 * \mathrm{P}<0.01 * * \mathrm{P}<0.001 * * *$, ns: not significant.

\begin{tabular}{|c|c|c|c|c|}
\hline Distance: 5 m & $\begin{array}{l}\text { Plant species } \\
\text { richness }\end{array}$ & $\begin{array}{l}\text { Entomophilous } \\
\text { plant cover }\end{array}$ & $\begin{array}{l}\text { Brassicaceae } \\
\text { cover }\end{array}$ & Family \\
\hline \multicolumn{5}{|l|}{ Herbivores and damage } \\
\hline Pollen beetles & - & ns & ns & Neg binomial \\
\hline Pollen beetle larvae & - & ns & $0.026+$ & Neg binomial \\
\hline Aphids & ns & $-0.062^{*}$ & $-\quad$ & Neg binomial \\
\hline Pod damage & - & - & ns & Gaussian \\
\hline Stem damage & ns & ns & $0.013^{*}$ & Gaussian \\
\hline \multicolumn{5}{|l|}{ Predators and parasitism } \\
\hline Ladybugs & - & ns & - & Neg binomial \\
\hline Hoverflies & ns & ns & - & Poisson \\
\hline Pollen beetle parasitism & ns & $-0.004^{*}$ & $-0.007^{*}$ & Gaussian \\
\hline Aphid parasitism & - & ns & - & Gaussian \\
\hline Distance: $\mathbf{5 0 ~ m ~}$ & $\begin{array}{l}\text { Plant species } \\
\text { richness }\end{array}$ & $\begin{array}{l}\text { Entomophilous } \\
\text { plant cover }\end{array}$ & $\begin{array}{l}\text { Brassicaceae } \\
\text { cover }\end{array}$ & Family \\
\hline \multicolumn{5}{|l|}{ Herbivores and damage } \\
\hline Pollen beetles & & ns & ns & Neg binomial \\
\hline Pollen beetle larvae & ns & ns & ns & Neg binomial \\
\hline Aphids & ns & ns & - & Neg binomial \\
\hline Pod damage & ns & ns & ns & Gaussian \\
\hline Stem damage & ns & $-0.003+$ & - & Gaussian \\
\hline \multicolumn{5}{|l|}{ Predators and parasitism } \\
\hline Ladybugs & - & ns & - & Neg binomial \\
\hline Hoverflies & ns & $-0.027+$ & - & Neg binomial \\
\hline Pollen beetle parasitism & $0.004^{*}$ & - & ns & Gaussian \\
\hline Aphid parasitism & ns & ns & ns & Gaussian \\
\hline
\end{tabular}


Table 3. Relationships betweesuppn entomophilous flowering plants species, natural enemy abundance and parasitism rate in wheat (A) and oilseed rape (B) fields. The model was only applied to response variables significantly correlated to the total cover of flowering entomophilous species. GLMM estimates and significance levels of explanatory variables are presented for the best model (lowest AIC). -: not retained by AIC, + P<0.1 $\mathrm{P}<0.05 * \mathrm{P}<0.01 * * \mathrm{P}<0.001 * * *$, ns: not significant.

\begin{tabular}{|c|c|c|c|c|c|c|c|c|c|c|}
\hline A) Wheat & $\begin{array}{l}\text { Galium } \\
\text { aparine }\end{array}$ & $\begin{array}{l}\text { Galium } \\
\text { mollugo }\end{array}$ & $\begin{array}{l}\text { Geranium } \\
\text { dissectum }\end{array}$ & $\begin{array}{l}\text { Papaver } \\
\text { rhoeas }\end{array}$ & $\begin{array}{l}\text { Vicia } \\
\text { sativa }\end{array}$ & $\begin{array}{l}\text { Bellis } \\
\text { perennis }\end{array}$ & $\begin{array}{l}\text { Leucanthemum } \\
\text { vulgare }\end{array}$ & $\begin{array}{l}\text { Ranunculus } \\
\text { bulbosus }\end{array}$ & $\begin{array}{l}\text { Rosa } \\
\text { canina }\end{array}$ & $\begin{array}{l}\text { Trifolium } \\
\text { pratense }\end{array}$ \\
\hline Hoverflies $5 \mathrm{~m}$ & ns & $0.256+$ & - & $0.837+$ & - & - & ns & - & - & - \\
\hline Ladybugs 50 m & & $-0.314^{*}$ & ns & - & - & - & $8.261^{* * *}$ & - & - & - \\
\hline Aphid parasitism $5 \mathrm{~m}$ & - & - & ns & $-0.088+$ & $-0.262^{*}$ & - & $1.547^{\star \star \star}$ & - & - & - \\
\hline B) Oilseed rape & $\begin{array}{l}\text { Galium } \\
\text { aparine }\end{array}$ & $\begin{array}{l}\text { Galium } \\
\text { mollugo }\end{array}$ & $\begin{array}{l}\text { Geranium } \\
\text { dissectum }\end{array}$ & $\begin{array}{l}\text { Papaver } \\
\text { rhoeas }\end{array}$ & $\begin{array}{l}\text { Vicia } \\
\text { sativa }\end{array}$ & $\begin{array}{l}\text { Geranium } \\
\text { molle }\end{array}$ & $\begin{array}{l}\text { Silene } \\
\text { latifolia }\end{array}$ & $\begin{array}{l}\text { Sinapis } \\
\text { arvensis }\end{array}$ & $\begin{array}{l}\text { Sonchus } \\
\text { asper }\end{array}$ & $\begin{array}{l}\text { Veronica } \\
\text { persica }\end{array}$ \\
\hline Aphids $5 \mathrm{~m}$ & - & ns & - & $-0.445+$ & - & - & - & $\mathrm{ns}$ & $-0.424+$ & - \\
\hline Hoverflies 50 m & - & - & - & ns & - & - & - & ns & ns & ns \\
\hline Pollen beetle parasitism 5 m & $-0.123^{*}$ & - & $0.016^{*}$ & $-0.035^{\star *}$ & $0.059^{*}$ & - & - & - & $0.032^{* *}$ & - \\
\hline Stem damage $50 \mathrm{~m}$ & - & ns & ns & ns & - & - & - & - & - & ns \\
\hline
\end{tabular}

